\title{
A PELE QUE NÃO HABITO: A FUSÃO HOMEM E BICHO NO CONTO “A PELE DO JUDEU” DE MÁRIO DE CARVALHO ${ }^{1}$
}

Antonia Marly Moura Silva²

\begin{abstract}
RESUMO: $\mathrm{Na}$ reconciliação do real com o imaginário, a literatura fantástica tem legitimado, pelo viés do símbolo e da alegoria, temores e indagações sobre a relação entre homem e bicho. Sedimentado no caráter subversor da realidade, figurações sombrias e de grande impacto emocional circunscrevem questões prementes sobre identidade, alteridade, integração natural ou experiência civilizada. É o que se verifica no conto "A pele do judeu", integrante da obra Contos da sétima esfera (1981) do português Mário de Carvalho. No relato, a metamorfose da personagem central realça a natureza lendária do enredo ao mesmo tempo em que destaca a jornada subjetiva que os seres ficcionais enfrentam em busca de si mesmos e dos mistérios da vida. É, pois, seguindo tal linha de reflexão que pretendemos analisar o referido conto à luz dos conceitos de Irène Bessière (1974), Julio Cortázar (1974), Roger Bozzetto (2001), David Roas (2014), Remo Ceserani (2006) dentre outros autores que em suas obras abrem um espaço promissor para o debate sobre a natureza do relato fantástico. Também muito oportunos são os postulados teóricos de Warnes (2012) e Gallagher (2009) sobre o motivo da metamorfose na literatura.
\end{abstract}

PALAVRAS-CHAVE: Conto português; fantástico, o animal na literatura.

\section{THE SKIN I DO NOT LIVE IN: FUSION BETWEEN MAN AND BEAST IN THE SHORT STORY “A PELE DO JUDEU” BY MÁRIO DE CARVALHO}

ABSTRACT: In the reconciliation between real and imaginary, fantastic literature has sanctioned, through symbol and allegory, fears and questions concerning the relationship between man and beast. Solidified in the subversive character of reality, somber figurations pertaining great emotional impact circumscribe pressing issues about identity, alterity, natural integration or civilized experience. That can be verified in the Portuguese author Mário de Carvalho's short story "A pele do judeu" ["The jew's skin"], from Contos da sétima esfera [Stories from the seventh sphere] (1981). In the story, the metamorphosis of the central character enhances the legendary nature of the plot inasmuch as it highlights the subjective journey that the fictional beings face in search of themselves and the mysteries of life. It is, therefore, following such reflection trail that the mentioned short story will be analyzed under the theories of Irène Bessière (1974), Julio Cortázar (1974), Roger Bozzetto (2001), David Roas (2014), Remo Ceserani (2006), among other authors who open a promising path for debating the nature of the fantastic story. Also, Warnes' (2012) and Gallagher's (2009) considerations about the metamorphosis motif in literature will be used.

KEYWORDS: Portuguese short story; fantastic, animal in literature.

Da tradição à modernidade, o tema da metamorfose despertou o interesse de poetas e contadores de histórias. A transformação de seres humanos em animais ou seres inanimados é motivo privilegiado em narrativas orais, em relatos bíblicos, nos contos de fada,

\footnotetext{
${ }^{1}$ Este texto é um fragmento dos resultados alcançados no âmbito do Projeto de Pós-Doutoramento intitulado $A$ arte da estranheza inexplicável: um estudo do conto fantástico no Brasil e em Portugal, realizado no período de 01 de fevereiro de 2016 a 01 de fevereiro de 2017 na Faculdade de Letras da Universidade de Coimbra, Portugal, sob a supervisão da Profa. Dra. Maria João Albuquerque Figueiredo Simões.

${ }^{2}$ É Professora Adjunto IV da Universidade do Estado do Rio Grande do Norte.
} 
na mitologia, dentre outros textos canônicos, literários ou não. Graças a Homero com sua Odisséia e aos relatos que integram as Metamorfoses de Ovídio, duas obras de grande influência na cultura ocidental, contamos com um rico manancial sobre tal fenômeno. De um modo geral, os processos de zoomorfismo e de antropomorfismo e outras manifestações de caráter metamórficos constituem recursos poéticos que até nossos dias continuam a seduzir, através do poder encantatório da linguagem, os mais céticos interlocutores.

Segundo Chevalier e Gheerbrant (1992, p. 608), “Todas as mitologias estão cheias de descrições de metamorfoses: deuses se transformam ou transformam outros seres em seres humanos, animais e, na maior parte dos casos, em árvores, flores, nascentes, rios, ilhas, rochedos, montanhas, estátuas". Na mitologia grega, o dom da metamorfose é restrito aos deuses, portanto, ligado ao poder divino. Geralmente, os deuses metamorfoseavam-se com o fim de punição, ciúme ou outro atributo. Os desígnios da transformação física, de acordo com Silva (2001, p. 22), “quase sempre se deve aos deuses onipotentes e tem objetivos de ordem prática. Serve de prêmio ou de castigo, ou então está colocada a serviço de fins libidinosos”. Em suma, a mitologia é rica em exemplos de transformação, deformação, antropormização, zoomorfização dentre outras peculiaridades ligadas ao caráter dual do ser humano ou inumano. Relatos bíblicos, contos de fadas, fábulas e narrativas populares, por sua vez, também integram discursos canônicos recheados de episódios e casos de transformação, hibridização e/ou antropormização/zoomorfização, dentre outros aspectos da metamorfose.

Assim, na tradição da configuração do medo, demônios, monstros, zumbis, ogros, visitantes noturnos, lobisomens, sapos e outras criaturas imaginárias compõem um variado repertório de narrativas que sustentam o princípio fundamental da metamorfose clássica. Neste território, povoado por fantásticas espécies e regido pelo princípio da fantasia, da magia e do mito, o corpo que muda de forma experimenta a migração da alma de um corpo para outro, no sentido da usurpação replicante ou do duplo, o que nos faz lembrar a visão oportuna de Marina Warnes que considera, na incidência da metamorfose à luz dos relatos ovidianos, o atributo da metempsicose, pensamento de Pitágoras sobre a ideia de que a alma nunca morre, mas se move de uma forma para outra, tomando todas e quaisquer formas. Segundo Warnes (2012, p. 3):

Thus Ovidian shape-shifting belongs on the one hand to the broad rubric of metempsychosis, the Phitagorean doctrine which holds that the soul, or essence of something or some person, migrates from one body to another. Forms do not only take on different forms; the whole of nature 
evolves through the creative power of shape-shifting and this transmigration of souls.

No universo mágico da visão clássica da metamorfose, o veículo sobrenatural compõe os meios de percepção do mundo. São significativas as ressonâncias míticas, o diálogo com as narrativas orais e, sobretudo, as influências ovidianas na representação da dualidade dos seres. $\mathrm{Na}$ sociedade moderna, influenciada pela ciência e pela tecnologia, parece não haver mais espaço para a difusão da magia, do poder divino e das fadas. Neste cenário, novos procedimentos interdiscursivos, temáticos e formais, são necessários para compor as faculdades do protagonista ficcional que se transforma em outro. Nesta linhagem, a obra Metamorfose de Franz Kafka inaugura uma nova perspectiva na representação do corpo que muda de forma, atributo até então concebido como coisa extraordinária e anormal. A transformação naturalizada do homem em inseto cria uma perspectiva inovadora frente a dimensão do real, pois, diante do insólito da metamorfose, os seres ficcionais não expressam sentimento de espanto. A irrealidade que circunda a transformação física parece monopolizar a racionalidade que constitui o cotidiano do personagem. O modo de fabulação da metamorfose tal como delineou Kafka incitou outras perspectivas romanescas, engenhosas e inusitadas, fundadas no entrecruzamento do possível e do impossível, do estranho e do familiar, universo estético em que localizamos grande variedade e diversidade de narrativas célebres reconhecidas na história da literatura por transgredir convenções formais e temáticas no modo de realçar aspectos da arquitetura ficcional, dentre os quais convém dar destaque a dualidade da personagem e a confluência de tempos e de espaços.

Convém ressaltar que o motivo da metamorfose, evento da esfera do sobrenatural, na literatura contemporânea é configurada como estranho, porém naturalizado num cotidiano familiar e verossímil. O esfacelamento de personagens é representado como traço inerente ao ser, endossando a confluência de elementos ordinários e extraordinários. Tal perspectiva pode ser compreendida como instrumento de renovação do "sentimento do fantástico" a que se refere Roger Bozzetto (2001), pois, tanto no plano simbólico como no plano literário, seus objetivos e as relações interdiscursivas evocam, de uma maneira ou de outra, contextos sociais e/ou ideológicos.

Nossa era, palco de incertezas, de desagregação social acelerada em que valores humanos são esvaziados de sentido, parece incitar figurações romanescas de novos monstros e dramas sobre a condição humana, daí a valorização de problemáticas em torno da identidade e da dualidade do ser. No caso específico da metamorfose, este procedimento estético parece beber na fonte dos textos canônicos e da mitologia antiga, pois Ovídio 
continua como referência norteadora no delineamento do tema. Segundo Gallagher (2009, p. 11):

Metamorphosis is a powerful and versatile concept that can be used in an almost inexhaustible number of ways in varying contexts to achieve different effects, and it has been adapted from Ovid's Metamorphoses to different literary styles and genres, from the fairy tale to poetry, prose writing, drama, and the modern German novel.

Do mesmo modo, declara Silva (2001, p. 23) que "[a] literatura ocidental credita a Ovídio o mérito de resgatado da Antiguidade o arquétipo da metamorfose”. Acrescenta ainda a autora que "o texto de Ovídio consegue manter uma unidade tal ao longo de tantos relatos diferentes que mesmo o leitor moderno, lendo-o em prosa e tradução, ainda se sente preso ao fascínio da palavra narrativa do poeta. (SILVA, 2001, p. 23)

Delineados assim, em termos da reflexão que pretendemos fazer sobre a relação binária entre homem e animal na literatura, e em especial, considerando a evolução de códigos sociais e estéticos que inspiram a renovação da problemática da metamorfose, pensamos ser essencial acrescentar a rede de ligações implicadas entre a metamorfose e o mito do duplo, nomeadamente situado em nossos dias em apropriações metafóricas que se alojam nos domínios do reflexo, da cisão/fusão da matéria, da hibridização, da antítese, da oposição e dos contrários corpóreos, dentre outros aspectos. Sob tal perspectiva, levantaremos um breve périplo conceitual sobre tal questão, levando-se em conta a ambiguidade e a ambivalência inerentes ao estatuto do duplo, questão fincada na grande tradição filosófica que nos fornece as teses principais da duplicação segundo a imperiosa prerrogativa da ilusão, traço que sustenta a natureza paradoxal do duplo de ser ao mesmo tempo ele próprio e outro, tal como concebe Clémente Rosset (1976).

Convém dizer que o mito do duplo é questão recorrente em relatos clássicos, literários ou não, matéria privilegiada na Psicanálise, na Literatura e nas Artes. Nos estudos literários, o interesse pelo tema do duplo pode ser observado em abordagens que focalizam sua manifestação em imagens e símbolos que denotam a dualidade constitutiva do ser humano. O duplo tem sido matéria de um debate milenar. Remonta a Platão, particularmente no capítulo VII de $A$ República, que na célebre alegoria da caverna, destaca o caráter dual da realidade, diferenciando a aparência da realidade. NO Banquete, o filósofo cita o mito de andrógino, a ideia originária de um homem uno e perfeito que, por transgredir as leis divinas, é punido com a divisão dos gêneros em masculino e feminino. Em decorrência desse ato, manifesta-se a busca incessante da metade perdida, visando o resgate da reconstituição das partes e da unidade primordial. 
O duplo configurou-se também nas imagens de gêmeos ou sósias, pondo em discussão o caráter multifacetado da cópia em detrimento do original. Vale ressaltar, de antemão, o caráter de substituição e as prerrogativas inerentes ao ser que se duplica, pois segundo Brunel (1987, p. 267) "aquele que se desdobrou (duplicou) cria para si à ilusão de agir sobre o exterior, quando na verdade não faz mais que objetivar seu drama interior."

$\mathrm{Na}$ modernidade, tal enfoque é ponto central porque nessa época não se tem a ilusão da personalidade una como ocorre com o sujeito do iluminismo, "indivíduo totalmente centrado, unificado", conforme nos lembra Hall (2006, p. 10). Para alguns, a ideia do homem moderno como sujeito estilhaçado é um traço decorrente de mudanças sociais e econômicas que vêm se processando ao longo do século. É com base em postulados dessa natureza que irrompe a concepção de que as identidades modernas são fragmentadas e incompletas.

$\mathrm{Na}$ literatura, foram muitos os que exploraram essas forças como matéria ficcional. É talvez por isso que, na prosa das últimas décadas do século XX, assistimos a permanência do tema do desdobramento do eu. Nesta perspectiva, consideramos oportuna a justificativa da pertinência do mito do duplo na atualidade. Na visão de Brunel (1998, p. 264):

O mito do duplo, no Ocidente, acha-se em estreita ligação com o pensamento da subjetividade, lançado pelo século XVII ao formular a relação binária sujeito-objeto, quando até então o que prevalecia era a tendência à unidade. Essa posição - concepção unitária de mundo/concepção dialética - é refletida reviravolta que sofre o mito literário do duplo. Desde a Antigüidade até o final do século XVI, esse mito simboliza o homogêneo, o idêntico: a semelhança física entre duas criaturas é usada para efeitos de substituição, de usurpação de identidade, o sósia, o gêmeo é confundido com o herói e vice-versa, cada um com sua identidade própria.

O duplo apresenta uma variedade de aspectos ligados ao esfacelamento do eu e outras formas de cisão/fusão de seres animados ou inanimados. De um modo geral, refere-se a um jogo de reflexos entre o "eu" e "outro", um jogo especular evocativo de aspectos como o contraste, a oposição, a também de semelhança e a complementaridade, dentre outros. $\mathrm{Na}$ visão de Otto Rank, dentre outras vertentes apontadas pelo estudioso, o duplo está relacionado às concepções antigas e superstições ligadas à expressão do mal e da morte. Segundo o referido autor (RANK, 1914 apud BRAVO, 1998, p. 263), “[...] o duplo é uma personificação da alma imortal que se torna a alma do morto, ideia pela qual o eu se protege da destruição completa, o que não impede que o duplo seja percebido como 'assustador mensageiro da morte"”.

Sob tal enfoque, a natureza do duplo contempla atributos duais relacionados aos pólos eu e não-eu, luz e sombra, vida e morte, estranho e familiar, instâncias que nos remetem 
a estranheza inquietante de que trata Freud em seu célebre texto "O inquietante" (1919) nos referimos a dualidade contida nos pares estranho/familiar defendida pelo psicanalista, a noção de que o estranho (ou inquietante) está relacionado a aquilo que causa medo, angústia e horror.

Conforme Freud (2010), o estranho diz respeito ao conhecido que ficou reprimido na mente humana e ressurge provocando uma sensação desagradável e ao mesmo tempo familiar. No que se refere a estranheza que circunda a problemática da morte, assim declara o estudioso: "é extremamente inquietante tudo o que se relaciona com a morte, com cadáveres e com o retorno dos mortos.” (FREUD, 2010, p. 269). Nesta perspectiva, o encantamento que se verifica na relação entre a personagem e a pele (morta), conforme a abordagem crítica do conto de Mário de Carvalho que segue, parece trazer à tona outros traços inquietantes do duplo, o que nos faz lembrar a declaração oportuna de Freud (2010, p. 353) sobre tal questão: “O caráter do inquietante pode proceder apenas do fato de o duplo ser criação de um tempo remoto e superado, em que tinha um significado mais amigo. $\mathrm{O}$ duplo tornou-se algo terrível [...]". Convém lembrar que o duplo, na visão oportuna de Bravo (1998, p. 263), baseada nos estudos de Keppler:

é ao mesmo tempo idêntico ao original e diferente - até mesmo o oposto
- dele. É sempre uma figura fascinante para aquele que ele duplica, em
virtude do paradoxo que representa (ele é ao mesmo tempo interior e
exterior, está aqui e lá, é oposto e complementar), e provoca no original
reações emocionais extremas (atração/repulsa).

À luz deste pensamento, é perceptível a natureza dual e paradoxal do conceito, que comporta um jogo antagônico entre categorias como "idêntico e diferente", "interior e exterior”, "aqui e lá”, “oposto e complementar", “atração e repulsa”. Dessa forma, é possível dizer que o duplo configura-se a partir de um paradoxo, pois a confluência e a cisão entre o original e a cópia ou mesmo a natureza do semelhante/dessemelhante originam a indecidibilidade que se aloja em torno da problemática da dualidade. Sob tal perspectiva, na própria natureza do duplo se aloja um caráter ambíguo e ambivalente, pois tal atributo comporta uma dialética indissolúvel como os polos eu e outro, eu e não-eu, o mesmo e um, questões prementes que são do âmbito da identidade e da alteridade, da identidade e da diferença.

Frente a isso podemos dizer que o duplo, regido pelo signo do esfacelamento, afirma o dinamismo de forças que interagem em favor do sentimento de incerteza perante as realidades objetivas, dando relevo a um jogo de oposição do tipo oposto e complemento, 
original e cópia, aqui e lá e, luz e sombra, morte e vida, dentre outros termos que evocam a duplicação, a contradição ou a união de elementos e de realidades.

\section{A representação fantástica do animal}

As narrativas populares, os contos maravilhosos e as fábulas de Esopo e de La Fontaine inauguraram, na tradição da ficção narrativa, a temática da animalização do homem ou a humanização do animal, acentuando valores e comportamentos humanos, bem como dramas protagonizados por criaturas enigmáticas que povoam o imaginário de todos os tempos. Não é necessário, entretanto, ir tão longe no tempo para levantar formas literárias que tornaram célebres a fusão entre homem e bicho. Na literatura moderna, alegórica ou metaforicamente, é abundante a ação de animais em situações atípicas, desencadeando sentimentos de empatia, de espanto e de medo. A incursão poética na dualidade humano/inumano, portanto, parece querer eliminar as fronteiras que separam a racionalidade e a irracionalidade.

$\mathrm{Na}$ tradição do medo, contadores de histórias e escritores investiram em diferentes recursos imagéticos para amedrontar, seduzir e encantar seu público. Na literatura fantástica, por sua vez, escritores acentuaram o estreitamento entre realidade e ficção para arrebatar as emoções do leitor e ampliar o efeito catártico do discurso romanesco. Assim, seres sobrenaturais oriundos do mito e do imaginário, concebidos em tradições e crenças como agentes da desordem e ameaças de vida, serviram para reforçar mistérios humanos, o desconhecimento do mundo e os perigos daí decorrentes. Convém destacar, no entanto, que o medo é um atributo cultural que evolui de acordo com a sociedade. Nesta perspectiva, no mundo moderno, comandado pela racionalidade e pela ciência, o modo de operar o sobrenatural, traço instigador da transgressão da realidade, também sofre mudanças em decorrência das transformações sociais. Desse modo, monstros, bruxas, ogros, fantasmas e vampiros - figuras que consagraram a literatura não realista, comumente associados como agentes do sobrenatural - parecem não funcionar mais como referências instigadoras dos temores modernos, o que nos motiva a identificar traços distintivos do modo fantástico de ontem em relação ao fantástico contemporâneo.

Nesta perspectiva, é importante considerar os contornos assumidos pelo fantástico na atualidade, predominantemente voltado para problemáticas em torno do eu ou da “dimensão interior", tal como se observa nas reflexões de Italo Calvino (2004). Uma 
evidência desta conclusão esta na perspectiva conceitual de que o fantástico evolui tal como a literatura e de acordo com a sociedade. Este é o ponto central em torno do qual se organiza uma variedade de ponto de vista sobre as novas configurações da realidade na literatura fantástica. O que se ressalta aqui são os contornos assumidos pelo fantástico contemporâneo, valendo-se das conquistas da literatura e da sociedade. Sob tal enfoque, consideramos oportuno o que ressaltam Bozzetto e Huftier (2004, p. 43):

Les récits "classiques" s'agrègent alors à de nouvelles optiques, plus en rapport avec l'evolution sociétale et littéraire: loin de se conformer à la prédiction de Todorov - qui ne voit qu'un seul type d'effet avec un corpus particulièrement restreint -, les textes effets de fantastique évoluent en même temps que la société et la littérature.

Nestes termos, aquilo é concebido como "clássico" ou compreendido como "moderno" tem a resposta na evolução mesma da literatura, pois conforme Jacques Finné (1980, p. 13), “Comme tout genre littéraire, le fantástique n’est pas statique. Il a évolué, au cours de as breve existence, à tel point qu'il mériterait non une thése, mais une série de théses".

É oportuno repetir que o fantástico se aloja no entrecruzamento de realidades, quando o natural e o sobrenatural se misturam de modo harmonioso. O fantástico ocorre quando um fenômeno de outra dimensão surge em um mundo semelhante ao nosso, esse fenômeno é o que configura o estatuto do sobrenatural, "aquilo que transgride as leis que regem o mundo real e não pode ser explicado porque não existe segundo essas leis (ROAS, 2014, p. 25). É própria da narrativa fantástica a expressão de um cenário realista que assegure a confluência de realidades - a verossímil e a inverossímil. Em síntese: enquanto o realismo firma um contrato mimético com a realidade, o fantástico transgride essa realidade, pois, não tem compromisso com a verdade. Porém, para que o insólito se aloje, o relato deve ser crível.

$\mathrm{Na}$ visão de Irène Bessière (2009, p. 3):

O relato fantástico utiliza marcos sócio-culturais e formas de compreensão que definem os domínios do natural e do sobrenatural, do banal e do estranho, não para concluir com alguma certeza metafísica, mas para organizar o confronto entre os elementos de uma civilização relativos aos fenômenos que escapam à economia do real e do surreal, cuja concepção varia conforme a época.

Roger Bozzetto (2001), por sua vez, destaca que imagens e efeitos fantásticos são característicos de cada época. Atento aos numerosos e diversos domínios do fantástico e seus efeitos no território literário, assim declara o estudioso (BOZZETTO, 2001, p. 5):

Les territoires des fantastiques sont multiples, et n'ont pas toujours été explores. Il en va de même des divers états du fantastique, qui 
ont produit et produisent encore pour chacun, des effets spécifiques, en relation avec des signifiants culturellement códes, mais traumatisants, comme le cauchemar, les monstres, les doubles, les vampires, Méduse etc. Chaque époque de la seule 'culture occidentale' a donné lieu à des prises en compte, dans l'imaginaire comme dans la réalité, de figures de l'horreur, de la terreur, de la monstruosité etc.

No desenho da (ir)realidade, os contos conferem à história uma atmosfera anormal num mundo aparentemente normal. Assim, o absurdo e a fantasia cumprem a função de deflagrar uma nova noção de real, sob uma dimensão irônica e crítica. Esse modo fabular de representar a realidade realça, por um lado, aspectos sobre a realidade social moderna, e, por outro, suscita reflexões sobre os dramas dos personagens, seres aparentemente normais em total descompasso com o mundo e, por isso, em situação de desequilíbrio em relação ao que enfrentam.

É, pois, seguindo tal linha de reflexão que faremos, a seguir, uma leitura do conto “A pele do judeu", integrante da obra Contos da sétima esfera (1981) do português Mário de Carvalho, tentando compreender a metáfora do animal na representação do discurso mimético e, em particular, na ação dos seres ficcionais. Interessa reconhecer a relação humano e inumano ou o estatuto dessa relação binária como signo representativo da transgressão das leis biológicas e das regras morais e sociais. Em síntese, a intenção é analisar a configuração dos personagens duplos, sujeitos da violação da ordem natural ou humana.

\section{A simbiose entre mulher e bicho no conto "A pele do judeu"}

Mário de Carvalho ${ }^{3}$, escritor aclamado pela crítica, é considerado um dos grandes representantes da literatura portuguesa contemporânea. Seu reconhecimento pode ser comprovado na repercussão de sua obra - não somente no panorama das letras portuguesas - nos diversos prêmios ${ }^{4}$ que recebeu ao longo da carreira literária, mas, sobretudo, na vasta e diversificada poética constituída de vinte e seis títulos, dentre romances, contos, novelas, crônica, teatro, ensaio e literatura infantil. Ao longo de sua vida literária, no entanto, o escritor demonstrou certa preferência pelo gênero narrativo, o mais cultivado em seu universo

\footnotetext{
${ }^{3}$ Nascido em Lisboa em 1944. Cidadão antenado com as questões políticas e sociais, foi membro do Partido Comunista Português, lutou contra a ditadura militar, preso e exilado em 1973, voltando para seu país após a revolução de 25 de abril de 1974.

${ }^{4}$ Recebeu diversos prêmios, com destaque para Contos Soltos (1986), Era uma vę um alferes (1984 - adaptado para televisão), Quatrocentos mil sestérios (1991 - ganhador do Grande Prêmio do Conto APE), Um deus passeando pela brisa da tarde (1994 - Grande Prêmio do Romance APE; Prêmio Pégasus e Prêmio Fernando Namora), Era bom que trocássemos umas ideias sobre o assunto (1997), conforme Silvia Niederauer (2008).
} 
ficcional, contabilizando seis romances - sendo O Livro Grande de Tebas, Navio e Mariana (1982), o primeiro deles - três novelas e dez coletâneas de $\operatorname{contos}^{5}$, um suposto indicador da matriz de seu projeto estético que, num exercício de mais de trinta anos, tem conquistado a admiração e o reconhecimento do público leitor pelo modo peculiar de narrar, pelo inusitado de suas temáticas e pela engenhosidade de sua poesia. Ou ainda, como defende Domingos Lobo (2013, p. 42), "pela inventiva, pelo rigor da estrutura, pela imagética que a consubstancia, pela fuga ao lugar-comum, pelo parónimo que a invade, por alguma estranheza que provoca em leitores menos destros (e em alguma crítica, convenhamos) "deslocada".

Desde sua estreia em 1981 com os Contos da sétima esfera, sua obra representou uma ruptura com o cânone literário, pois transgrediu convenções estéticas, notadamente apontadas pelos estudiosos da área. No caso particular de seus primeiros contos, assim declara Silvestre (1998, p. 212):

impressionam desde logo pela revelação de um universo ficcional
pessoalíssimo e intransmissível, a vários títulos estranhos à nossa tradição
literária: eles são no seu virtuosismo efabulatório e no seu camaleonismo
estilístico, a revelação pública de um notável escritor, que o é também pela
confiança com que adopta uma estratégia de reivindicação da
"menoridade" contra as entidades sacrais do cânone literário, a começar
pela inevitável hierarquia dos gêneros.

Sobre o estatuto de sua ficção, é comum o destaque para certas constantes temáticas, dentre as quais convém destacar a revitalização da História de Portugal, a problematização do imaginário nacional e a reflexão metaficcional (ARNAUD, 2012), ou seu “'fascínio’ pela romanidade", como declara o próprio escritor (CARVALHO, 2012, p. 11). Neste contexto, digno de nota é o diálogo intertextual de sua ficção com temas consagrados na tradição grecolatina, em particular, com atributos clássicos associados aos problemas da sociedade e do homem contemporâneo (SANTOS, 2012). Expressivos também são alguns procedimentos estilísticos como a ironia, o humor e a paródia consagrados pelo escritor em seu discurso romanesco. Apesar do destaque dado aos aspectos metaficcionais na obra de Mário de Carvalho, realçando-se o cruzamento da literatura com a história, é lugar comum o reconhecimento de sua predileção pelo fantástico em seu discurso romanesco; "herdeiro do neo-realismo, do fantástico, do humor setecentista", como ressalta Lobo (2013, p. 42), o

${ }^{5} \mathrm{O}$ último, Ronda das mil belas em frol, uma coletânea de dezessete contos, foi lançado no mercado editorial português em setembro de 2016 pela Porto Editora, versa sobre sexo e ligações íntimas entre homens e mulheres. 
escritor enaltece com maestria traços distintivos do fantástico, pois, conforme lembra Almeida (2013, p. 104), em sua narrativa,

subitamente, num mundo ordenado, irrompe um elemento estranho que vem criar o caos, para depois desaparecer, deixando uma espécie de inquietação que nunca se apagará. Pode ser um anjo da guarda que coloca ao lado de um professor, nunca o abandonando, um chimpanzé que resolve escrever A menina e Moça ou ainda uma nuvem que insiste em molhar os habitantes do Beco das Sardinheiras: Mário de Carvalho diz-nos que o mundo se rege por leis inexplicáveis e só resta aos humanos uma capacidade ínfima de acção.

Ainda sobre determinantes na obra do escritor português, Silvestre (1998, p. 213) aponta duas vertentes ficcionais:
duas grandes linhas de desenvolvimento: uma que previlegiará o fantástico, o fabulário, o absurdo quotidiano, a conciliação e o cruzamento de temporalidades históricas e míticas, e que optará preferencialmente pela forma curta, do conto ao texto epigramático, por vezes com feições gnómicas [...] outra, bastante mais 'realista' tendendo a recorrer a formas mais extensas, da novela ao romance ... em que o autor se entrega às suas desencantadas meditações morais sobre o homem enquanto animal político"

O conto “A pele do judeu” integra os Contos da sétima esfera - obra constituída de vinte e três narrativas, distribuídas em três partes. É o décimo terceiro da coletânea e último da segunda parte. Na narrativa, a aliança entre o mistério e a fantasia endossa a atmosfera de irrealidade que marca a intriga do relato, fundamentando o dilema inquietante da essência do ser e da verdade. Podemos dizer que a trama encontra-se configurada em duas etapas que se fundem no desfecho: a primeira apresenta a busca do conhecimento e a segunda revela o espectro da verdade em torno da dualidade da figura feminina.

O tema da procura, articulado no interior do discurso romanesco, evoca um processo de retorno às origens. A função cósmica da busca, expressa na ação dos personagens, é um signo de desterritorialização e de procura da própria identidade, pois a ação praticada pelos seres ficcionais - o estrangeiro pesquisador Rui e a enigmática Magda - corroboram e reafirmam o desejo de acesso a um passado ou um princípio de vida.

Todo o investimento da narrativa está no cruzamento de realidades: do passado com o presente, do verossímil com o inverossímil, do árabe com o português, do mistério com a realidade, da mulher com a serpente. Trata-se da história do universitário Rui Telmo, que, em Lisboa, sobretudo na Biblioteca Nacional, investiga a vida dos Árabes na Península. Narrado em terceira pessoa, o conto detalha o mistério existente por trás dos livros e, 
sobretudo, a incógnita em torno da personagem Magda, a começar pelo modo inusitado como a mulher é localizada pelo pesquisador. Tudo começa durante um momento de busca na Biblioteca, quando, por acaso, o jovem encontra, junto a um texto sobre as minas de prata de Lisboa, uma anotação a lápis, constituída de versos e um número de telefone. Com contornos de uma incógnita, à noite, acontece o encontro entre os dois. O estranhamento da situação se entende para o modo de figuração da jovem mulher, descrita como "pequena e macilenta, de gestos nervosos, indecisos". (CARVALHO, 1990, p. 139)

A mulher, com seu "jeito antigo ou estrangeiro" (CARVALHO, 1990, p. 139), conforme destaca o narrador, configura-se como um ser supostamente deslocado no tempo e no espaço, pois: "Vestia saia longa, muito travada, como noutro tempo se usou" (CARVALHO, 1990, p. 139). Os olhos da figura feminina constitui outro dado curioso na narrativa, uma vez que, referido recorrentemente, ora "eram pardos, enormes, ora claros, ora escuros, de tonalidade azulada, violeta, quase negra conforme a ênfase do seu discurso" (CARVALHO, 1990, p. 139). A mudança na cor dos olhos de Magda é um traço textualmente destacado pelo narrador: "fixou em Rui os seus grandes olhos, agora de um cinzento límpido como o mar de certas invernias" (CARVALHO, 1990, p. 140). Essa oscilação no corpo da mulher parece antecipar a problemática central da história, a fusão mulher e bicho que ocorrerá no desfecho da trama, na transformação da personagem em serpente. O mistério em torno da figura feminina se estende para o local de sua morada, localizada "muito, muito longe" (CARVALHO, 1990, p. 140), o que sugere uma passagem para outra esfera da realidade, ou para um outro tempo. Ao passar pela porta da casa de Magda, Rui ocupa um espaço-tempo que parece não ser medido pelo relógio, ou a confluência que remete ao conceito bakhtiniano de cronotopo, ou seja, "os índices do tempo transparecem no espaço, e o espaço reveste-se de sentido e é medido com o tempo. Esse cruzamento de séries e a fusão de sinais caracterizam o cronotopo artístico” (1988, p. 211).

Os traços figurativos para a representação do ambiente embaralham e confundem a lógica e a razão, pois acentuam a estranheza da situação narrada. Aos olhos do leitor, sugestões sonoras e imagéticas reforçam um cenário de caos e de desordem: é a lenta porta que abre, uma iluminação fosca, metade do quarto ocupado por um elefante de verga, o contraste entre o escuro e o colorido de uma máscara africana empenachada, um desvão, repleto de antigos trastes, um amontoado de caixas, restos de mobílias, dentre outros aspectos. Em síntese, o mobiliário, a iluminação e os adereços contribuem decisivamente para deflagrar o mistério e a atmosfera difusa e confusa da realidade ou o entrecruzamento 
de tempos que circundam a personagem. O que nos faz lembrar a declaração oportuna de Remo Ceserani (2006, p. 73) sobre "a passagem da dimensão do cotidiano, do familiar e do costumeiro para a do inexplicável e do perturbador: passagem de limite, por exemplo, da dimensão da realidade para a do sonho, do pesadelo, ou da loucura”. Em síntese, a realidade circunscrita no universo ficcional do conto, é desestabilizada pelo desconhecido, por traços que não são familiares, por isso, configura-se como ameaçador. Nessa perspectiva, é tarefa árdua para o leitor tentar demarcar fronteiras entre o possível e o impossível. Convém dizer que é nesse liame em que o fantástico atua de modo a transgredir a realidade. "Uma transgressão que ao mesmo tempo provoca o estranhamento em relação à realidade, que deixa de ser familiar e se converte em algo incompreensível e, como tal, ameaçador". (ROAS, 2014, p. 134-135).

No conto, os personagens parecem peregrinar entre o passado e o presente, entre a imaginação e a fantasia, situam-se na fronteira entre o mundo dos vivos e o mundo dos mortos, questão, metaforicamente, sugerida na imagem do pergaminho em pele humana, "uma pele de judeu, morto há tantos anos que já não havia de arrepiar nem razão de alarme..." (CARVALHO, 1990, p. 141). Emblemática, ainda, é a morte misteriosa de Rui no desfecho da narrativa.

Magda, como uma engenheira, com compasso e régua em punho, traceja, meticulosamente a busca, guiada pelos sinais de pigmentação da pele estendida no chão, a localização exata das minas que ambos tencionam descobrir, as pistas que possivelmente permitirão desvendar o enigma do mistério. As minas se constituem, aos olhos dos seres ficcionais, como um espaço simbólico, fronteira com o desconhecido; o referido espaço é retomado várias vezes na narrativa, parece representar o entrelugar que demarca o elo entre dois mundos, supostamente contrários.

Assim, num sábado, um dia ensolarado, os dois transitam entre rochas e pedregulhos, em busca das minas de prata de Lisboa. Na cena, a oposição estranho-familiar se instala a começar pelo vestuário da mulher, que, embora ciente da árdua tarefa de escavação e poeira, como é de se esperar no espaço das minas, aparece com um vestido vermelho, inadequado para a tarefa, mas possivelmente, atendendo ao rigor do rito de passagem sugerido na estrutura da narrativa:

Rui estranhava-lhe o vestir, o menos adequado a quem diz querer pesquisar entre torrões e poeiras. Desta vez, Magda trazia um longo vestido decotado, vermelho, brilhante, quase refulgente ao sol, e em volta do pescoço faiscava-lhe o que parecia ser um rosicler de prata, pesado, 
lavrado, em completo contraste com os ornamentos simples do outro dia. (CARVALHO, 1990, p. 143)

No conto, a atmosfera fantástica se aloja na menção às trevas, no momento em que os personagens encontram um buraco negro na terra, "três túneis negros", a possível fenda para a invasão de uma outra lógica no cotidiano dos personagens, uma possível passagem para um mundo desconhecido e incerto, descida metafórica que assinala o acesso para um lugar alhures, para além do tempo e do espaço real. Se por um lado, o clima de terror e a atmosfera inquietante acentuam o medo de Rui, por outro lado não causam qualquer desconforto à heroína, que encara a situação como naturalizada e, portanto, familiar, o que se pode inferir a partir do ponto de vista do narrador ao revelar como a mulher conduz a busca pela escuridão da caverna. A descrição do interior da mina onde se realiza a investigação está constituída de metáforas associadas ao reino animal e ao escuro. As referências circunstanciais dão indicações da linha emocional que distancia Rui, personagem transitória, da soberania da moça que transita pelo seu suposto habitat natural. Em outras palavras, figurações imagéticas e sensoriais reiteram a estranheza da mulher situada entre a razão e o instinto. Paredes negras, entulhos, chão granulado, dentre outros aspectos da ambientação, ilustram a natureza associal da vida da heroína, que se mostra totalmente integrada ao espaço.

É importante ressaltar que a escuridão que impulsiona a manifestação do medo experimentado por Ruy constitui traço promissor nos domínios da representação insólita, denotando "a preferência do fantástico pelos mundos tenebrosos, subterrâneos, do além, sobrenaturais", como aponta Ceserani (2006, p. 79). A irrealidade no conto se aloja no processo de transformação do corpo da mulher, apontado em diversos momentos da narrativa, ora na atitude de "coxear, balançando fortemente o corpo a cada passo" (CARVALHO, 1990, p. 145) ora na referência ao "ritmo das oscilações do corpo de Magda". Estranha é também a confluência da figura feminina com a rocha: "E a Rui veio a sensação estranha, inexprimível, de que o corpo de Magda e a sombra de Magda, marcada irregularmente na rocha pelo claror do archote, se confundiam". (CARVALHO, 1990, p. 145). Acrescente-se, ainda, o momento em que a personagem parece abandonar o corpo de mulher para metaforicamente transformar-se em outro ser: “O corpo de Magda então cresceu, parece encher todo o túnel, todos os espaços em volta, e Rui debateu-se contra um turbilhão zunidor, de cores vermelho-vivas, que o revolveu, suspendeu nos ares e lançou ao chão”. (CARVALHO, 1990, p. 146). 
No relato, a transformação de Magda em serpente adquire os contornos de um ritual sagrado e de narrativa mítica. Os signos icônicos do redemoinho e do tremor da terra, herdados da matriz mitológica, realçam elementos irreais que conferem ao gesto da metamorfose o substrato da magia e do encantamento, prerrogativas da relação com o imaginário e com o misterioso e traços comuns no conto popular, nos contos fantásticos tradicionais, valorizados com técnica e engenhosidade na narrativa de Mário de carvalho.

\section{Considerações finais}

A representação da relação entre bicho e ser humano em “A pele de judeu” de Mário de Carvalho permite apontar certa inspiração na tradição oral e mais especificamente no modo de fabulação do mito arcaico, o que pode ser observado na emblemática transformação da personagem feminina em bicho. No conto, o autor preserva a perspectiva verossimilhante durante todo o enredo. Somente no final da narrativa acontece um evento transgressor da realidade. Os fatos narrados acontecem num mundo real, sem qualquer tipo de acontecimento que a razão não possa explicar, porém, no desfecho do relato, um fato misterioso e inexplicável acontece. Ao conflito é dada uma saída que não tem explicação racional. O conto parece apropriar-se, metaforicamente, do conteúdo mítico, em particular do mito do "eterno retorno", para compor a restauração de uma cena originária, quando o ser duplo retorna ao seu babitat natural.

A arquitetura ficcional permite, ainda, apontar certas associações sobre a própria estrutura do relato, considerando o que afirma Piglia (2004, p. 90-91) sobre o gênero conto. Assim declara o autor: "um relato visível esconde um relato secreto, narrado de um modo elíptico e fragmentário", o que se verifica em "A pele do judeu", narrativa com desfecho inesperado que sugere, de imediato, uma aproximação com o formato de conto à moda de Poe. A narrativa parece moldurar duas histórias - a história vivida pela mulher e, outra, a secreta, de um outro tempo, in princípio, ou como quer Eliade (1991, p. 54) ao referir-se ao tempo mítico ou sagrado, "qualitativamente diferente do tempo profano, da contínua e irreversível duração na qual está inserida nossa existência cotidiana e dessacralizada". Assim, podemos dizer, que, emblematicamente os seres ficcionais evocam um "passado" através de uma representação simbólica - uma pele de judeu - que permite recuperar um passado e experimentar uma ilusão de existência. 
O fantástico nesse conto fundamenta-se no confronto entre dois mundos: o ordinário e o extraordinário, tal como declara Caillois sobre tal vertente: “[...] o fantástico é ruptura da ordem reconhecida, irrupção do inadmissível no seio da inalterável legalidade quotidiana, e não a substituição total do universo real por um universo exclusivamente maravilhoso" (apud FURTADO, 1980, p. 19). O tratamento conferido à relação binária humano/inumano e o modo como tal problemática se articula no cotidiano dos seres ficcionais são procedimentos ilustrativos do fantástico contemporâneo, pois o real e o irreal se misturam harmoniosamente. No conto "A pele do judeu" a personagem central, uma mulher, vivencia um processo lento de bestialização, num cenário tenso de mistério, pois, no final do relato, o humano desaparece para dar vez ao animal. $\mathrm{Na}$ ação dos personagens humanos, figurados como ancestrais, supõe-se uma regressão às origens. Sob o signo da "pele que habito" ou "que não habito", na tradição da fábula, a incursão na animalização humana se inscreve através da metamorfose corporal, pois a mulher vive situações atípicas, comportamentos desordenados que não são da natureza humana, até o desfecho final, quando ocorre a transformação física, a migração de almas, pois a forma humana é transformada em animal e, assim, as personagens evadem para o habitat animal. Há uma sugestão metafórica de passagem ou um retorno às origens. Desse modo, a morte é a única saída para o resgate original da espécie. De uma forma geral, as narrativas se desenvolvem sob o signo do corpo (im)possível.

Em síntese: a naturalização do irreal, tal como é configurada no relato, parece constituir-se como mais uma forma de provocar um pacto com o leitor. Possivelmente, um modo de instigá-lo a refletir sobre a essência, a função e a natureza da literatura; de suscitar reflexões para além da imanência da obra, realçando a evolução de códigos estéticos e, sobretudo, a relação de contiguidade entre literatura e sociedade, passado e presente, literatura e mito, razão e desrazão.

\section{Referencias}

ALMEIDA, Teresa. A arte de inquietar: percurso sobre a ficção de Mário de Carvalho. In: Mário de Carvalho: homenagem à vida e obra. Escritaria, Penafiel, 2015. pp. 103-119.

AUGRAS, M. O duplo e a metamorfose: a identidade mítica em comunidades nagô. 2. ed. Petrópolis, RJ: Vozes, 2008.

ARNAUD, Ana Paula. A paixão do Conde de Fróis: paródia e subversão. In: SILVA, Maria de Fátima; BARBOSA, Teresa Virgínia Ribeiro. (Org). Ensaios sobre Mário de Carvalho. Coimbra: Imprensa da Universidade de Coimbra, 2012. pp.189-200. 
BAKHTIN, Mikhail. Questões de literatura e de estética: a teoria do romance. São Paulo: Hucitec, 1988.

BESSIÈRE, Irène. O relato fantástico: forma mista do caso e da advinha. Fronteiraz Trad. D’Angelo, B. \& Oliveira, M. R. D. São Paulo, PUC-SP, 3(1), 2009, 1-18. Disponível em http://revistas.pucsp.br/index.php/fronteiraz/issue/view/875. Acesso em 26 de Novembro de 2013.

BOZZETTO, Roger. Le fantastique dans tous ses états. Aix-en-Provence: Publications de L’Université de Provence, 2001.

BOZZETTO, Roger \& Huftier, Arnaud. Les frontières du fantastique: approches de l'impensable em littérature. Paris: Presses Universitaires de Valenciennes, 2004.

BRAVO, Nicole Fernandez. O duplo. In: BRUNEL, Pierre. (org). Dicionário de mitos literários. 2. ed. Rio de Janeiro: José Olympio, 1997. p. 261- 293.

CALVINO, Ítalo. Introdução. Contos fantásticos do século XIX: o fantástico visionário e o fantástico cotidiano. São Paulo: Companhia das Letras, 2004. p. 9-18.

CARVALHO, Mário. (1990). Contos da sétima esfera (2a ed.). Lisboa: Caminho.

—. Entrevista com Mário de Carvalho. Disponível em: http.//www.homemmag.pt/pt/index.php/arte-e-literatura/arquivo-arte-e-literaaura/87luisa-costa-gomes-entrevista-mario-de-carvalho

$$
\text { Folheando com Mário de Carvalho. Disponível em: }
$$

http://www.portaldaliteratura.com/entrevistas.php?id=39.

CESERANI, Remo. O fantástico. Curitiba: Editora UFPR, 2006.

CHEVALIER, Jean e GHEERBRANT, Alain. Dicionário de Simbolos: mitos, sonhos, costumes, gestos, formas, figuras, cores, números. 6. ed. Rio de Janeiro: José Olympio, 1992. ELIADE, Mircea. Imagens e símbolos: ensaios sobre o simbolismo mágico-religioso. Trad.

Tamer, S. C. São Paulo: Martins Fontes, 1991.

FREUD, Sigmund. O estranho. Obras completas de Sigmund Freud. Rio de Janeiro: Imago, 1990. v. 18. p. $12-85$.

FURTADO, Filipe. A construção do fantástico na narrativa. Lisboa: Livros Horizonte, 1980.

GALLAGHER, David. Transformations of the body and the influence of Ovid's metamorphosis on Germanic literature of the nineteenth and twentieth centuries. New York: Editions Rodopi B. V. Amsterdam, 2009.

HALL, Stuart. A identidade na pós modernidade. 11. ed. Tradução de Tomaz T. da Silva e Guacira L. Lovro. Rio de Janeiro: DP \& A. 2006. 
LOBO, Domingos. Rigor e reinvenção: o universo literário de Mário de Carvalho. In: Mário de Carvalho: homenagem à vida e obra. Escritaria, Penafiel, 2015. pp.41-50.

OVÍDIO. Metamorfoses. Tradução Vera Lúcia Leitão Magyar. São Paulo: Madras, 2003.

PIGLIA, Ricardo. Formas breves. São Paulo: Companhia das Letras, 2004.

PLATÃO. O Banquete ou Do amor. 2. ed. Trad.; introdução e notas de J. C. de Souza. São Paulo: Difusão Europeia do Livro, 1999.

República. Trad. de Enrico Corvisieri. São Paulo: Nova Cultural, 2000.

ROAS, David. A ameaça do fantástico: aproximações teóricas. São Paulo: Editora da UNESP, 2014.

ROSSET, Clèment. O real e seu duplo: ensaio sobre a ilusão. 2. ed. Rio de Janeiro: José Olympio, 2008.

SANTOS, Rosana Baptista dos. Fabulário: (Re)contando mitos. In: SILVA, Maria de Fátima; BARBOSA, Teresa Virgínia Ribeiro. (Org). Ensaios sobre Mário de Carvalho. Coimbra: Imprensa da Universidade de Coimbra, 2012. p. 249-271.

SILVA, Vera Maria Tietzmann. A metamorfose nos contos de Lygia Fagundes Telles. 2. ed. Goiania: Editora da UFG, 2001.

SILVESTRE, Osvaldo Manuel. Mário de Carvalbo: revolução e contra-revolução ou um passo trás e dois à frente. Revista Colóquio/ Letras, 1 (147/148), 1998, 209-229.

WARNES, Marina. Fantastic metamorphoses other worlds. Ways of telling the self. New York: Oxford University Press, 2012. 